\title{
Pinpointing Unrest at Palmyra in the Early Islamic Period The Evidence from Coin Hoards and Written Sources
}

\author{
EMANUELE E. INTAGLIATA
}

\begin{abstract}
This article collates the evidence of coin hoards from Palmyra in order to reflect on the causes behind some of the most dramatic events that befell the city in Late Antiquity and early Islam. After having stressed the importance of coin hoards as sources to reconstruct the city's past by looking at a couple of examples dated to the fourth century AD, the article moves on to the early Islamic period. It argues that the unusual concentration of coin hoards dated to the second half of the seventh century suggests that the city underwent a period of unrest at that time and reflects on the causes that might have triggered it.
\end{abstract}

Keywords: Palmyra, Late Antiquity, early Islamic period, coin hoards, Kitāb al-Aghān̄̄, unrest

Emanuele E. Intagliata, Centre for Urban Network Evolutions (UrbNet), Aarhus University, Aarhus; e.e.intagliata@cas.au.dk; e.e.intagliata@gmail.com

It has already been suggested elsewhere that the numismatic evidence from Palmyra is rather problematic for drawing the history of the city in Late Antiquity (AD 273-634) and the early Islamic period (AD 634-750). ${ }^{1}$ The relative high occurrence of fourth-century issues from the Sanctuary of Baalshamin and the excavations of the Polish team suggest that the city survived the dramatic events of AD 272-273..$^{2}$ Since the fourth century, Palmyra was home to the Legio I Illyricorum, which might have functioned as a veritable economic engine for the urban community, as Roman soldiers were often keen on spending their rich wages in brothels, taverns and markets. ${ }^{3}$ The drastic drop in the quantity of coins in the fifth century is an obstacle to shed light on the 'Dark Age' of the settlement; however, it is important to keep in mind that this reduction does not necessarily translate into a general decline of the urban life of Palmyra. Fifth-century issues are rather difficult to retrieve archaeologically,

\footnotetext{
${ }^{1}$ Intagliata 2018.

${ }^{2}$ Intagliata 2015; Kowalski 1997.

${ }^{3}$ Macmullen 1963: 92. The Notitia Dignitatum (Not. Dig., Or., 7.34) remains the only primary source attesting the presence of the Legio I Illyricorum. On the garrison of Palmyra, see: Kowalski 1998; Intagliata 2015: 169-175.
} 
and it is likely, therefore, that this drop depends on the nature of the evidence rather than historical circumstances. The sixth century, which is reported by written sources to have been a period of revitalisation for the settlement, ${ }^{4}$ is also rather poorly represented in the numismatic record. Finally, the Islamic presence in the city is difficult to identify by just looking at coins, as Byzantine issues remained in circulation for a long while after the conquest of the city in 634 .

Despite these drawbacks, it is still possible to reconstruct the main vicissitudes that the inhabitants of Palmyra withstood by looking at the numismatic record, as patchy and incomplete as the historical narrative might turn out to be. In this sense, the laudable publication of the numismatic record gathered by the Polish archaeological team in over 50 years of excavations in the city remains crucial for this discussion. ${ }^{5}$ Key to reconstructing the history of the city is the publication of coin hoards. Coin hoards may be used to provide insights into the dramatic events that might have befallen Palmyra, as among the most important indicators of unrest in bygone societies. In total, four post-Roman coin hoards have been found in Palmyra, all dated between the fourth and the mid-eighth centuries. This paper aims to collate the evidence of Late Antique and early Islamic coin hoards in the city to reach a better historical understanding of the site after the fall of Zenobia (AD 272). It will first discuss a number of case studies dated to Late Antiquity in which a presence of coin hoards has already been linked to dramatic changes in the settlement's history. It will, then, explore the evidence for the early Islamic period, arguing that the coin hoards deposited in the second half of the seventh century might be associated with a phase of general urban unrest.

\section{COIN HOARDS IN LATE ANTIQUE PALMYRA}

In Late Antiquity, Palmyra might still have been very much attached to its Roman past. However, in the archaeological record, this Roman legacy is only faintly visible. The funerary inscription of Odenathos dated to the mid-fifth century would suggest that Palmyrene names were still in vogue at the time. ${ }^{6}$ Pagan religion survived in the city in the fourth century; the inscription of Avitus optio princeps dedicated to Zeus the Highest in 302 in the Sanctuary of Baalshamin is one of the most remarkable pieces of evidence of this. ${ }^{7}$ One could argue that the ingrained pagan identity of the city might have even survived for a long while throughout Late Antiquity, although evidence from the archaeological evidence and written sources would suggest otherwise. ${ }^{8}$

In spite of evidence of continuity, the archaeological record points clearly to drastic changes in this period. The fall of Zenobia (AD 272) and the second Palmyrene revolt (AD 273) brought about major destructions in the city, if one can believe the writings of

\footnotetext{
4 Proc., Aed., 2.11.10-12; Mal., Chr., 17.2. See also: Theop., Chr., 1.174, who follows Malalas.

5 Krzyżanowska, Gawlikowski 2014.

6 Yon 2012: 374, n. 494.

7 Yon 2012: 163-164, n. 154.

8 See: Drijvers 1982: esp. 36.
} 
Zosimus and the author of the Historia Augusta, Vita Aureliani. ${ }^{9}$ In the late third or beginning of the fourth century, a new fortress was constructed in the city (the so-called Camp of Diocletian), resulting in a change of role for Palmyra, which, from being a caravan city, became an important military outpost along the eastern frontier. ${ }^{10}$ Major changes were also caused by the process of Christianisation, which saw the demise of pre-existing pagan sanctuaries and the construction of churches. ${ }^{11}$

There is very little of this historical narrative that can be underpinned by looking at coin assemblages. The Polish excavation of the northwest quarter has uncovered, not far from the Bellerophon Hall, a wooden box opened '[...] as if emptied by a robber [...]'. This contained gold fragments, a stylus, a bronze seal ring and four coins minted under Gallienus (AD 260-268) (Fig. 1:1). The coins provide a convenient terminus for its deposition that fits well into the accounts of destructions and pillaging unfolding in the early $\mathrm{AD} 270$ s as a result of the Aurelianic siege. ${ }^{12}$ A thick destruction layer of charcoal found further to the south, in the Great Colonnade, would support this conclusion. ${ }^{13}$ It remains to be disentangled as to why a robber would leave gold fragments and coins untouched on the ground.

More substantial is the evidence from the Camp of Diocletian, and, specifically, the Sanctuary of Allat. Here, at the end of the fourth century, the main temple suffered pillage and destructions. The face of the cult statue of Athena, was disfigured with a number of well-aimed blows. This has been associated with a thick destruction layer that included some two hundred fragments of terracotta lamps dated to the fourth century. ${ }^{14} \mathrm{~A}$ coin of Aelia Flavia Flacilla, first wife of Theodosius I (AD 376-386), found in a gap between the floor slabs of the temple would support a date to the mid- or late-380s for these actions. The destruction of the temple has been associated with the visit to the city of Maternus Cynegius, Praefectus Praetorio Orientis and well-known physical executor of the anti-pagan measures undertaken by Theodosius I at the time. ${ }^{15}$ From the northeast part of the adyton of the same building comes also a coin hoard of 45 bronze Roman issues (Fig. 1:2). The coins were originally placed in a pot and were found covered by the fragments of the destroyed cult statue of Athena. Besides a third-century issue, the other coins of the assemblage are all fourth century in date. The latest is dated to AD 383-395 and might suggest that the destruction of the temple occurred later than the $\mathrm{AD} 380 \mathrm{~s}^{16}$

Although the visit of Maternus Cynegius to the city is admittedly difficult to prove with hard evidence, one cannot deny that the late fourth century coincided with a rather

\footnotetext{
${ }^{9}$ Hist. Aug., Vita Aur., 31.5-9; Zos., Hist. Nov., 1.60-61.

${ }^{10}$ The foundation inscription of the fortress is in: Yon 2012: 132-133, n. 121 (with further bibliography). A summary description of the military compound can be found in: Kowalski 1998.

${ }^{11}$ Summary descriptions of the churches in Palmyra are by Gawlikowski $(1993 ; 2001)$ and Westphalen (2009).

${ }^{12}$ Gawlikowski 2004: 323.

13 Żuchowska 2000: 187.

${ }^{14}$ Gąssowska 1982.

15 Gąssowska 1982.

${ }^{16}$ Krzyżanowska 2014: 55.
} 


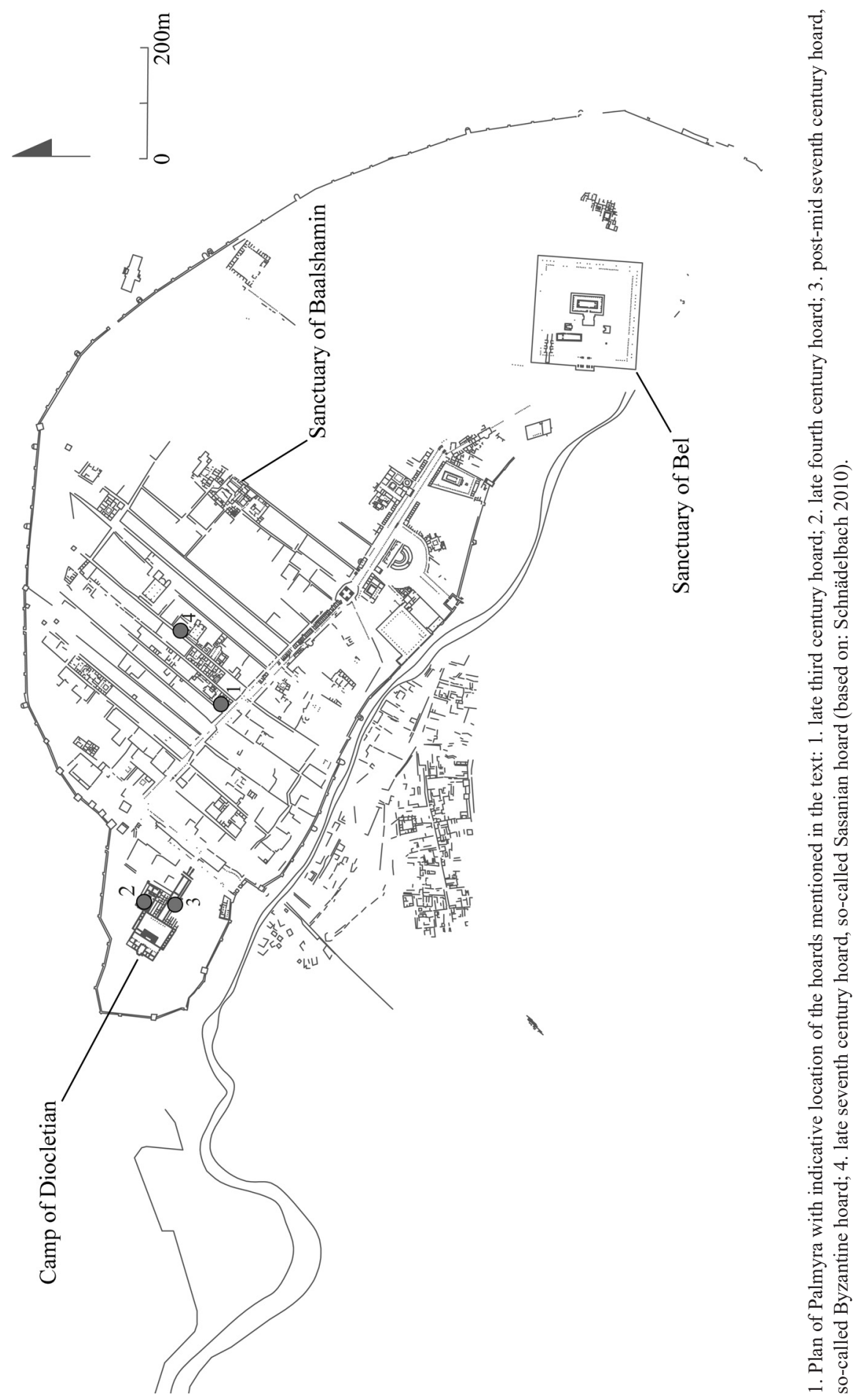


dramatic change in the religious habit of the settlement. Besides the destruction recorded in the Sanctuary of Allat, it is worth mentioning a secondary, but still rather informative, case study. This is from the northwest quarter, where the Polish team uncovered the remains of a luxurious Roman private residential building. The house originally included a dining hall with a $9 \mathrm{~m}$ by $5.50 \mathrm{~m}$ large mosaic in the mid-third century. ${ }^{17}$ The mosaic is embellished by two central panels, one showing a hunter shooting an arrow at a tiger and the other, which gives the name to the hall, picturing Bellerophon fighting the Chimaera. The later history of the mosaic is well-known. After AD 273, possibly as early as the beginning of the fourth century, the hall was transformed into a meeting place by a religious community. ${ }^{18}$ This transformation is archaeologically visible and attested by the addition of two poor-quality mosaics that include two black and white panels featuring two pairs of open hands - a symbol commonly associated to the Anonymous God. ${ }^{19}$ In the late fourth century, the Bellerophon Hall underwent another important transformation. New dwellers found no use in the Roman mosaic, which was hidden by a more practical mortar floor. ${ }^{20}$ It is tempting to associate the abandonment of this place with the vicissitudes that the Sanctuary of Allat was experiencing in the same period and see in these events a rather programmatic way to dispose of the city's pagan past.

\section{EARLY ISLAMIC PERIOD}

The two most dramatic events that unfolded in Palmyra from the fifth to the mid-seventh century are virtually invisible in the archaeological record. ${ }^{21}$ The Persian occupation (AD 611-629) has not yet been archaeologically proven. The same applies for the Islamic conquest of AD 634. Arabic medieval written sources are full of anecdotes on the conquest of Palmyra by treaty (șulhan) and not by force ('anwatan) by Khālid b. al-Walīd;'22 however, no destruction layers associated to this event have ever been brought to light, supporting the theory of a smooth transition between the two powers. The two most iconic early Islamic monuments that best represent the city at the time are the Umayyad $S \bar{u} q$, in the western stretch of the Great Colonnade, ${ }^{23}$ and a mosque installed in an existing structure (the so-called Caesareum). ${ }^{24}$ The urban community was living within the perimeter of the city wall, but it was not contracting. Evidence from, among others, the Peristyle Building

17 Gawlikowski 2004: 313.

18 Gawlikowski 2004: 318.

19 Gawlikowski 2004: 318.

20 Zuchowska 2006: 445.

21 Summary descriptions of Palmyra in the early Islamic period are in: Gawlikowski 2009; Intagliata 2015: $265-277$.

${ }^{22}$ Among the sources reporting the fall of Palmyra are: Ibn 'Asākir, Tā'rīkh, 2.80; al-Balādhurī, Futūh, 111-112; Ibn al-Faqīh, Mukhtașar, 125; Ibn A'tham al-Kūfī, Kitāb, 1.140-142; al-Ṭabarī, Tā'rīkh, 4.2109; al- 'Ușfurī, Tā' rìkh, 1.124; al-Wāqidī, al-Maghāzì, 1.44; al-Ya 'qūbī, Tā'rīkh, 2.134; Yāqūt, Mu 'jam, 1.832. See also the poem by al-Qa 'qā' b. 'Amr reported in Ibn 'Asākir, Tā'rīkh, 2.132.

23 al-As‘ad, Stępniowski 1989.

24 Genequand 2008; 2012: 52-66; 2013. 
and House F suggest that the Roman private residential buildings were being still inhabited, although they were experiencing major transformation in terms of plan and architecture. ${ }^{25}$ The houses and workshops in the Via Praetoria of the Camp of Diocletian and the northern courtyard of the Sanctuary of Baalshamin suggest that it remained vital for the inhabitants of Palmyra to exploit every inch available within the city wall. ${ }^{26}$

Two coin hoards dated to the second half of the seventh century attest the presence of a community that was certainly not struggling for survival. The first in order of discovery is a relatively rich assemblage brought to light in 1960 in the Camp of Diocletian by the Polish archaeological team led by Kazimierz Michałowski. The hoard, which was originally in a green glazed pot, was found in a chamber against the back wall of the southern portico of Via Praetoria, 5.60m west of the Groma of the military compound (Fig. 1:3) ${ }^{27}$ The hoard contained six pieces of jewellery (two rings, two earrings, one pendant in the shape of a cross and another unidentified object, interpreted as a 'pendeloque ou élément d'une parure') and a coin assemblage of 27 gold issues. These include nine issues of Phocas (AD 602-610), 13 pieces of Heraclius's sons (AD 613/614-638), and one coin of Constans II (AD 641-668) dated to the eight indiction (AD 649/650), all minted at Constantinople. ${ }^{28}$ The mid-seventh century date provides a convenient terminus for the deposition of the hoard that might be explained historically, as discussed below. At the time, the Camp of Diocletian had lost its military function, either since the Persian occupation of the city or, later, the Islamic conquest, and taken on a more modest residential/productive purpose. ${ }^{29}$

Two more coin assemblages were found in the northwest quarter by the Polish team and dated roughly to the same chronological horizon (Fig. 1:4).$^{30}$ The largest of these, the so-called Sasanian Hoard, was originally placed in a textile bag and might have accounted as much as 750 silver dirhams. It was found along Church Street against the corner of a stretch of the street paved with slabs and limited by four columns. The day after this discovery, the excavators uncovered a second concentration of 18 coins (either a second hoard or part of the first hoard) some $2 \mathrm{~m}$ to the north of the first. In the final publication of these assemblages, 694 coins were described by Michał Gawlikowski. As already stated by this scholar, the importance of this coin hoard is indisputable; the assemblage is one of five Sasanian hoards attested in Syria and, among these, it seems to be the earliest. Its earliest issues are dated to the reign of Kavād I (AD 499-531) and most of them (67\%) were minted during the Sasanian occupation of Syria. The latest are Arab-Sasanian dirhams minted between $\mathrm{AD} 683$ and 695 . The hoard was found in an unsealed natural deposit together with two post-reformed filūs (eighth-ninth century). This has led to the hypothesis being posited that the assemblage had been preserved as a saving hoard with no further addition for about one century, until the final demise of the city centre in the early ninth

\footnotetext{
25 Grassi, al-As'ad 2013; Gawlikowski 2007.

26 Michałowski 1960: 70-75; 1962: 54-77; 1963: 41-60; Intagliata 2017.

27 Michałowski 1962: 60-66, 223-236.

28 Stefan Skowronek in Krzyżanowska 2014: 60-64.

29 Gawlikowski 1976: 155; 1994: 136.

30 Gawlikowski 2002: 266-269; 2005: 463; 2009: 91; 2014: 71-120.
} 
century. ${ }^{31}$ As discussed below, however, an alternative interpretation might be given to its deposition based on the evidence from written sources.

The occurrence of these hoards dated roughly to the same chronological horizon cannot be dismissed as a mere coincidence, especially if one looks back at the pattern of deposition of coin hoards in late antique Palmyra, which are all associated to a rather dramatic change in the history of the settlement. Their disposal in different areas of Palmyra recalls a pattern already seen in the late fourth century and would incline us to believe that dramatic events unfolded at the time involving the city in its entirety.

A glance at the historical background might help provide an answer to the reason behind their deposition. At the time, the city was the political centre of the powerful Banū Kalb, a Yemenite tribe originally from northwest Arabia that retained an important role in supporting the Umayyad caliphate in Damascus. ${ }^{32}$ During the civil war between 'Abd al-Malik b. Marwān and the usurper 'Abdallāh b. al-Zubayr, the Umayyads were at Tadmur (Palmyra). ${ }^{33}$ They had been driven out of Mecca, Medina and Hijāz by Ibn al-Zubayr and had found refuge at Tadmur, where they received an oath of allegiance by the inhabitants of the city. Eventually, the support of the Palmyrenes proved to be indispensable to Marwān to defeat al-Ḍaḥhāk b. Qays, who was on Ibn al-Zubayr's side, at Marj Rāhit, near Damascus, in 684. The support of the Palmyrenes at Marj Rāhit is reported by Abū Mikhnaf, as quoted by al-Tabarī. ${ }^{34}$ Later, Ibn al-Athīr would take as accurate Abū Mikhnaf's narration and succinctly reported the same episode. ${ }^{35}$ If Abū Mikhnaf's account is taken as valid, it would suggest that the people of Palmyra played an active role in maintaining the caliphate in power.

What came after Marj Rāhit might have set the background for the deposition of the hoards in Palmyra. The battle at Marj Rāhit triggered an intertribal conflict between the Qays, who at Marj Rāhit were on Ibn al-Zubayr's side and suffered considerable losses, and the Yemenites, including the Kalbites led by Humayd b. Harīth b. Bahdal. Involved in the fights against the Banū Kalb were mainly the Banū 'Āmir, guided by Zufar b. Hārith al-Kilābī, who established himself in Qarqesīa after the battle, and the Banū Sulaym, whose leader was 'Umayr b. Hubāb. The latter had at first been on 'Abd al-Malik's side but, after Marj Rāhit, defected and joined Zufar b. Hāarith in Qarqesīa. ${ }^{36}$

The conflict between these two factions would have long historical implications whose full narration is not necessary for the scope of this discussion. However, an episode reported in Kitāb al-Aghānī (The Book of Songs) suggests that the early development of the feud involved directly the inhabitants of Palmyra. Kitāb al-Aghānì is a lengthy (five thousand folios) tenth-century unfinished collection of songs written by Abū al-Faraj al-Ișfahān̄i.

31 Gawlikowski 2014: 71.

32 On the association of Tadmur with Banū Kalb, see, e.g.: Agapius, Kitāb, 515; Ibn 'Asākir, Tā'rīkh, 17.326, 63.337; al-Ișfahānī, al-Aghānī, 17.112, 20.120; al-Ṭabarī, Tā'rīkh, 9.1796, 1893.

33 Ibn 'Asākir, Tà'rīkh, 55.261.

34 al-Ṭabarī, Tä'rīkh, 7.482.

35 Ibn al-Athīr, al-Kāmil, 4.125.

36 Wellhausen 1963: 201-202. 
The work is not a chronicle, but contains important insights on a number of historical events that are often presented to contextualise songs. ${ }^{37} \mathrm{Abū}$ al-Faraj al-Ișfahānī reports that the feud arose when Zufar b. Hārith decided to attack a settlement at al-Mușayyakh, where twenty members of the Banū Kalb were killed. In retaliation, the Kalbites slaughtered some members of the Banū Numayr (one of the tribes of the Qays) who were living with them at Tadmur. The episode is reported twice in al-Ișfahān̄̄s Kitāb al-Aghānī. In Book 17 (see Appendix below), the author simply reports that the head of the Kalbites, Humayd b. Harīth b. Bahdal, broke an existing treaty between the Banū Numayr and the Banū Kalb and massacred the members of Banū Numayr. ${ }^{38}$ In Book 20 (see Appendix below), the episode is recounted in more detail. Humayd b. Harîth b. Bahdal is said to have reached Tadmur and imprisoned the people of the Banū Numayr. A Kalbite, Mațar b. 'Awș, was left there to guard them, but, before leaving, in a moment of anger, Humayd ordered Matar to kill the prisoners. He realised only later the consequences of his order and immediately sent a messenger to Tadmur to prevent the massacre. However, it was apparently too late to stop Mațar who, by the time the messenger reached the city, had already executed 60 men. ${ }^{39}$

The two passages in al-Iṣfahānī's Kitāb al-Aghānī are informative in many ways. First, they suggest that the term 'Palmyrenes' in the early Islamic period would have hidden a complex urban community comprised of different tribes co-existing in the same townscape. The delicate and fragile balance of this co-existence had its roots in much more complex political dynamics that went well beyond the limits imposed by the city wall. It would be unfair, then, to dismiss the history of Palmyra in the early Islamic period as being of merely local significance. Secondly, if placed alongside the coin hoards discussed above, the passages in Ișfahānī's Kitāb al-Aghānī would suggest that the city might have been experiencing at the time urban unrest motivated by political circumstances, the extent of which is difficult to assess given the lacunose state of the archaeological record. In no way, however, did the settlement disappear from history because of this. Archaeological evidence, as seen above, would suggest that the city centre was abandoned only in the ninth century. The collapse of the Umayyad dynasty in AD 750, and the associated end of the Kalbite power, was certainly one of the main reasons behind this negative turn in the history of the settlement.

It would be a mistake, however, to rely fully on al-Ișfahān̄̄s Kitāb al-Aghānī in explaining the reasons behind these hoards' depositions. Arabic writers are known to be not particularly interested in reporting events for the sake of history. The historiography of the futūh (early Islamic conquests), to cite one, revolves mainly around the necessity of inciting people to the $j i h \bar{a} d$, justifying the Muslim rule and glorifying individuals and families with accounts of the deeds of their ancestors..$^{40} \mathrm{Al}$-Ișfahānī's historical accounts often revolve around people rather than events, as the writer was interested in reflecting on the ethics

\footnotetext{
37 On Al-Ișfahān̄̄, Kitāb al-Aghān̄̄, see also: Kilpatrick 2003 (with extensive bibliography).

38 al-Ișfahānī, al-Aghānī, 17.112-113.

39 al-Ișfahānī, al-Aghān̄i, 20.120-121.

40 Donner 1998: 177-179; see also: Robinson 2003: 143-155 (with extensive bibliography).
} 
of human behaviour. ${ }^{41}$ His reliability as a historical source is, therefore, not unquestioned. A second issue of Al-Ișfahānī's work is his reliance on different sources, a well-known tendency among Arabic writers that often causes challenging contradictions within the same text. ${ }^{42}$ Disentangling fact from fiction in this and other early Islamic Arabic writers, is, therefore, a frustrating exercise that can often lead to dead ends.

As tantalising as this connection between coin hoards and al-Ișfahānī's Kitāb al-Aghānī might be, this should be taken, therefore, cum grano salis. Indeed, other historical circumstances might have triggered the deposition of these hoards, one of them perhaps being growing tensions between Muslims and Christians. ${ }^{43}$ One should note, in fact, that the hoard in the Camp of Diocletian included a cross and that those in the northeastern quarter were deposited in front of an ecclesiastical building next to a church. At Palmyra, Christians remained active after the Muslim conquest of the city of $\mathrm{AD}$ 634, the latest documented bishop of the city being John from the monastery of Mār Hanania appointed in $\mathrm{AD} 818 .{ }^{44}$ It is likely that frictions between the two communities might have occurred, although there is, admittedly, little archaeological evidence to support this and written sources are silent on this regard. ${ }^{45}$

\section{CONCLUSIONS}

Coin hoards are one of the best indicators of unrest in past societies. The case study of the hoard of Roman coins from the adyton of the Sanctuary of Allat is, for example, indicative of the dramatic transformations in religion that the city experienced in the late fourth century. The unusual concentration of coin hoards recently published by the Polish team and dated to the second half of the seventh century might suggest that the city was similarly going through a troubled period in the early Islamic period. This paper has attempted to reflect on the causes behind these early Islamic hoard depositions. A close look at Kitāb al-Aghān $\bar{\imath}$ would suggest that, in the aftermath of the battle of Marj Rāhit, the city was involved in the intertribal conflict between the Qays and the Yemenites, which caused the killing of members of the Banū Numayr in Palmyra. Although the deposition of these hoards cannot be directly associated with this massacre, their existence might be proof of the troublesome political framework under which the city was operating at that time. We should, however, be cautious in connecting problematic written sources and archaeological evidence to shed light on circumstantial historical events and not exclude other potential cause behind these coin hoards. One of these might well be growing tensions between Muslims and Christians living within the same urban environment. For this, however, we, admittedly, lack written sources for Palmyra, while archaeological evidence remains scanty.

${ }^{41}$ Kilpatrick 2003: 160-161.

42 Kilpatrick 2003: 151.

${ }^{43}$ The present author is very grateful to the anonymous reviewers of this article for this idea.

${ }^{44}$ Mich. Syr., Chr., 3.453.

${ }^{45}$ The order of the caliph, Uthmān b. 'Affān (644-655), to remove crosses from the streets might have motivated the necessity to conceal a cross carved on the lintel of the main entrance of the Praetorium in the Camp of Diocletian (Kowalski 1994: 58; see: Intagliata 2018: 49). 


\title{
APPENDIX: TRANSLATION OF RELEVANT TEXTS
}

\author{
al-Ișfahānī, Kitāb al-Aghānī, 17.112-113
}

'Umayr began approaching quickly. He left Qarqisīyā and approached an edge of the Wādī Kalb. He attacked it and anyone he met of the people of Quḍā'a and al-Yaman. He provoked the people of Kalb and Taghlib before the war between Qays and Taghlib had started. So, he made the Bedouins take vengeance on all the people of the villages. Thus, when the people of Kalb saw what happened to their companions and that they were not able to resist the horsemen of the city, they gathered under the leadership of Humayd b. Hurayth b. Bahdal. He set out with them until they camped at Tadmur, where Banū Numayr resides. There was an agreement [still valid] between the Banū Numayr, in particular, and the people of Kalb who were in Tadmur together with b. Bahdal b. Ba'āj al-Kalbī. The people of Numayr sent messengers to Humayd imploring him concerning its sanctity, but Ibn Ba'àj al-Kalbī attacked and slaughtered them, and then they [Banū Kalb] sent them a message: 'We have broken the treaty that was between us and you. Thus, try to go wherever you can'. So, they met and he [Humayd b. Hurayth b. Bahdal] killed b. Ba'āj and defeated the people of Numayr and they killed extensively and took captives.

al-Iṣfahānī, Kitāb al-Aghānī, 20.120-121

When Humayd b. Hurayth b. Bahdal came to know of what had befallen his folk, he proceeded to Tadmur to gather his men and launch a raid on Qays. When the bloodshed ensued, the Banū Numayr advanced from the valley where they were stationed near their waters towards Humayd b. Hurayth b. Bahdal until they approached the latter who was preparing for the raid. The tribe of Kalb unanimously gathered to support him. The Banū Numayr told him: 'Only if you intend to free us from blame and ensure our safety will we stay. If you threaten us with your folk, we shall return to our people'. Thereupon he replied: 'Do you wish to become their ushers until this conflict is resolved?'. Saying this, he detained them. His deputy in Tadmur was a man from Kalb called Mațar b. 'Awṣ. He was a ruthless warrior. When Humayd decided to kill them, Mațar refused since he did not prefer bloodshed. When Humayd mobilised his men to contain Zufar who had returned seeking more raids, he stationed his men in a friendly village. There he was informed of Zufar's return whereupon he was enraged and began to prepare for a counterattack. Matar, who had accompanied Humayd in order to kill the captured Numayrīs, approached Humayd and asked: 'What should I do with these prisoners now that the people of Musayyakh have been killed?'. Overcome with grief and no longer in control of his faculties, he replied: 'Go and kill them'. Matar quickly returned to Tadmur so as to not frighten them. Upon reaching Tadmur, he killed them. When Humayd regained his senses, he said: 'Where is Mațar, I wish to give him instructions?'. Those present replied: 'He returned (to Tadmur)'. 
Thereupon he exclaimed: 'Rush to stop him, that enemy of God, I fear the fate of the Numayrīs I have entrusted him with!'.

Humayd sent a horseman in pursuit of Matar with instructions to not kill the captives. When the messenger reached him, Mațar had already killed all of them except two. They were sixty men in total.

\section{Acknowledgements}

I am grateful to Ahmed Hussien, Teba Tarek, Andrew Marsham, and Jakko Hämeen-Antilla for their help in translating the Arabic sources. Alessandro Gnasso has greatly helped with his comments on the final draft of this paper. The anonymous reviewers have greatly contributed with their comments to this article. Any mistakes, however, remain wholly my own.

\section{References}

al-As'ad, K., Stępniowski, F.M. 1989: The Umayyad Suq in Palmyra, DamMitt 4, 205-223

Donner, F.M. 1998: Narratives of Islamic origins. The beginnings of Islamic historical writing, Studies in Late Antiquity and Early Islam 14, Princeton

Drijvers, H. 1982: The persistence of pagan cults and practices in Christian Syria, [in:] Garsoïan, N.G., Mathews, T.F., Thomson, R.W. (Eds), East of Byzantium: Syria and Armenia in the formative period, Dumbarton Oaks Symposium 1980, Washington, 35-43

Gawlikowski, M. 1976: Le Camp de Dioclétien : bilan préliminaire, [in:] Palmyre. Bilan et perspectives. Colloque de Strasbourg 18-20 octobre 1973, TCRPOG 3, Strasburg, 153-163

Gawlikowski, M. 1993: Eine neuentdeckte frühchristliche Kirche in Palmyra, [in:] Ruprechtsberger, E.M. (Ed.), Syrien: von den Aposteln zu den Kalifen, Mainz a/Rhein-Linz, 150-157

Gawlikowski, M. 1994: Palmyra, PAM V, 133-143

Gawlikowski, M. 2001: Le groupe épiscopal de Palmyre, [in:] Evers, C., Tsingarida, A. (Eds), Rome et ses provinces: genèse et diffusion d'une image du pouvoir. Hommages à Jean-Charles Balty, Bruxelles, 119-127

Gawlikowski, M. 2002: Palmyra, season 2001, PAM XIII, 257-269

Gawlikowski, M. 2004: Palmyra. Season 2003. Preliminary report, PAM XV, 313-324

Gawlikowski, M. 2005: Palmyra. Palmyra 2004, PAM XVI, 461-465

Gawlikowski, M. 2007: Beyond the colonnades: domestic architecture in Palmyra, [in:] Galor, K., Waliszewski, T. (Eds), From Antioch to Alexandria: recent studies in domestic architecture, Warsaw, 79-94

Gawlikowski, M. 2009: Palmyra in the early Islamic time, [in:] Bartl, K., Moaz, A.R. (Eds), Residences, castles, settlements. Transformation processes from Late Antiquity to early Islam in Bilad al-Sham. Proceedings of the international conference held at Damascus, 5-9 November 2006, Orient-Archäologie 24, Damascus, 89-96 
Gawlikowski, M. 2014: Le trésor Sasanide, [in:] Krzyżanowska, A., Gawlikowski, M., Monnaies des fouilles Polonaises à Palmyre, Studia Palmyreńskie XIII, Warsaw, $71-120$

Gąssowska, B. 1982: Maternus Cynegius, Praefectus Praetorio Orientis and the destruction of the Allat temple in Palmyra, Archeologia (V) XXXIII, 107-123

Genequand, D. 2008: An early Islamic mosque in Palmyra, Levant 40/1, 3-15

Genequand, D. 2012: Les établissements des élites omeyyades en Palmyrène et au ProcheOrient, $B A H$ 200, Beyrouth

Genequand, D. 2013: Between Rome and Islam: recent research on the so-called Caesareum of Palmyra, [in:] Fifty Years of Polish Excavations in Palmyra 1959-2009, International Conference, Warsaw, 6-8 December 2010, Studia Palmyreńskie XII, Warsaw, 97-114

Grassi, M.T., al-As'ad, W. 2013: PAL.M.A.I.S. Recherches et fouilles d'une nouvelle Mission conjointe syro-italienne dans le quartier sud-ouest de Palmyre, [in:] Fifty Years of Polish Excavations in Palmyra 1959-2009, International Conference, Warsaw, 6-8 December 2010, Studia Palmyreńskie XII, Warsaw, 115-128

Intagliata, E.E. 2015: Palmyra/Tadmur in Late Antiquity and early Islam. An archaeological and historical reassessment, unpublished $\mathrm{PhD}$ thesis, University of Edinburgh, Edinburgh

Intagliata, E.E. 2017: The post-Roman occupation of the northern courtyard of the Sanctuary of Baalshamin in Palmyra; a reassessment of the evidence based on the documents at the Fonds d'Archives Paul Collart, Université de Lausanne, Zeitschrift für Orient-Archäologie 9, 180-199

Intagliata, E.E. 2018: The unpublished archival material from the Fonds d'Archives Paul Collart, University of Lausanne; the numismatic record of the Sanctuary of Baalshamin, RIN 119, 15-30

Kilpatrick, H. 2003: Making the great book of songs. Compilation and the author's craft in Abû 1-Faraj al-Işbahânî's Kitâb al-Aghânî, London-New York

Kowalski, S.P. 1994: The Praetorium of the Camp of Diocletian in Palmyra, Studia Palmyreńskie IX, 39-70

Kowalski, S.P. 1997: Late Roman Palmyra in literature and epigraphy, Studia Palmyreńskie X, Warsaw, 39-62

Kowalski, S.P. 1998: The Camp of Legio I Illyricorum in Palmyra, [in:] Dyczek, P. (Ed.), Acta of the International Conference Wykno, Poland, 18-22 November, Novensia 10, [Warsaw], 189-209

Krzyżanowska, A. 2014: Monnaies grecques et romaines, [in:] Krzyżanowska, A., Gawlikowski, M., Monnaies des fouilles Polonaises à Palmyre, Studia Palmyreńskie XIII, Warsaw, 13-70

Krzyżanowska, A., Gawlikowski, M. 2014: Monnaies des fouilles Polonaises à Palmyre, Studia Palmyreńskie XIII, Warsaw

MacMullen, R. 1963: Soldier and Civilian in the Late Roman empire, Harvard historical monographs 52, Cambridge, Mass. 
Michałowski, K. 1960: Fouilles Polonaises 1959, Palmyre I, Warszawa-La Haye-Paris Michałowski, K. 1962: Fouilles Polonaises 1960, Palmyre II, Warszawa-La Haye-Paris Michałowski, K. 1963: Fouilles Polonaises 1961, Palmyre III, Warszawa Robinson, C.F. 2003: Islamic historiography, Cambridge

Schnädelbach, K. 2010: Topographia Palmyrena. 1: Topography, Documents d'archéologie syrienne 18 , Bonn

Wellhausen, J. 1963: The Arab kingdom and its fall, Beirut

Westphalen, S. 2009: Die byzantinischen Malereien im Beltempel und der Kirchenbau Palmyras: ein Resümée', [in:] Eichner, I., Tsamakda, V. (Eds), Syrien und seine Nachbarn von der Spätantike bis in die islamische Zeit, Spätantike - Frühes Christentum - Byzanz, Kunst im ersten Jahrtausend, Reihe B: Studien und Perspektiven 25, Wiesbaden, 155-165

Yon., J.-B. 2012: Palmyre, IGLS XVII/1, BAH 195, Beirut

Żuchowska, M. 2000: Quelques remarques sur la grande colonnade à Palmyre, BEO 52, 187-193

Żuchowska, M. 2006: Palmyra. Excavations 2002-2005 (insula E by the Great Collonnade). Preliminary report, PAM XVII, 439-450

\section{Primary sources}

Agapius, Kitāb: Agapius, Kitāb al- 'Unwān, Ed. and transl. A. Vasiliev, PatrOr 8/2.2, 1912, 391-547

al-Balādhurī, Futūḥ: al-Balādhurī, 'Aḥmad b. Yaḥyā, Futūḥ al-Buldān, Ed. M.J. de Goeje, Leiden 1866; transl. P.K. Hitti, New York 1916

al-Iṣfahānī, al-Aghānī: al-Iṣfahānī, Abū al-Faraj, Kitāb al-Aghān̄̄, Būlāq 1867-1869 [n.p.] al-Ṭabarī, Tā'rīkh: al-Ṭabarī, Muhammad b. Jarīr, Tā'rīkh al-rusul wa-l-mulūk, Eds M.J. de Goeje et al., Leiden 1879-1901; transl. VV. AA., Albany 1989-2007

al- 'Ușfurī, Tă'rīkh: al- 'Ușfurī, Abū 'Amr Khalīfah b. Khayyāt al-Laythī, Tā'rīkh, Ed. A.D. al- 'Umarī, Nağaf 1967 [n.p.]

al-Wāqid̄̄, al-Maghāzī: al-Wāqidī, Muḥammad b. 'Umar, Kitāb al-Maghāzī, Eds W. Nassau

Lees, F. Carbery, Calcutta 1854

al-Ya 'qūbī, Tả'rīkh: al-Ya 'qūbī, Aḥmad b. Abī Ya 'qūb b. Wāḍiḥ, Tā'rīkh b. Wāḍiḥ, Ed. M.J. de Goeje, Leiden 1960

Ibn 'Asākir, Tă'rīkh: Ibn 'Asākir, 'Alī b. al-Ḥasan, Tā'rīkh madīnat Dimashq, Ed. 'U.G. al- 'Amrawī, Beirut 1995-2000

Ibn A tham al-Kūfì, Kitāb: Ibn A'tham al-Kūfî, Abū Muḥammad Aḥmad, Kitāb al-Futūḥ, Ed. M. 'A. al-Mu' īd Khān, Hyderabad 1968

Ibn al-Athīr, al-Kāmil: Ibn al-Athīr, 'Alī 'Izz al-Dīn, al-Kāmil fī al-Tā' rīkh, Ed. C.J. Tornberg, Leiden 1866-1871

Ibn al-Faqīh, Mukhtașar: Ibn al-Faqīh al-Hamadhān̄i, Aḥmad b. Muḥammad b. Isḥāq Abū Bakr, Mukhtașar kitāb al-buldān, Ed. M.J. Goeje, Leiden 1885

Hist. Aug., Vita Aur: Historia Augusta, Vita Aureliani, Ed. and transl. F. Pashoud, Paris 1996 
Mal., Chr: John Malalas, Chronographia, Ed. L.A. Dinforf, Bonn 1831; transl. E. Jeffreys, M. Jeffreys, R. Scott, Melbourne 1986

Mich. Syr., Chr.: Michael the Syrian, Chronicle, Ed. and transl. J.-B. Chabot, Paris 1899-1910

Not. Dig.: Notitia Dignitatum, Ed. O. Seeck, Berlin 1876

Proc., Aed.: Procopius, De Aedificiis, Ed. and transl. H.B. Dewing, London-New York 1961 Theop., Chr: Theophanes, Chronographia, Ed. C. de Boor, Leipzig 1884

Yāqūt, Mu 'jam: Yāqūt b. 'Abdallāh al-Hamaw̄̄ al-Rūmī al-Baghdādī, Kitāb mu'jam al-buldān, Ed. F. Wüstenfeld, Leipzig 1866-1873; transl. G. Le Strange, London 1890

Zos., Hist. Nov.: Zosimus, Historia Nova, Ed. and transl. F. Paschoud, Paris 2000 


\section{ÉTUDES et TRAVAUX XXXI / 2018}

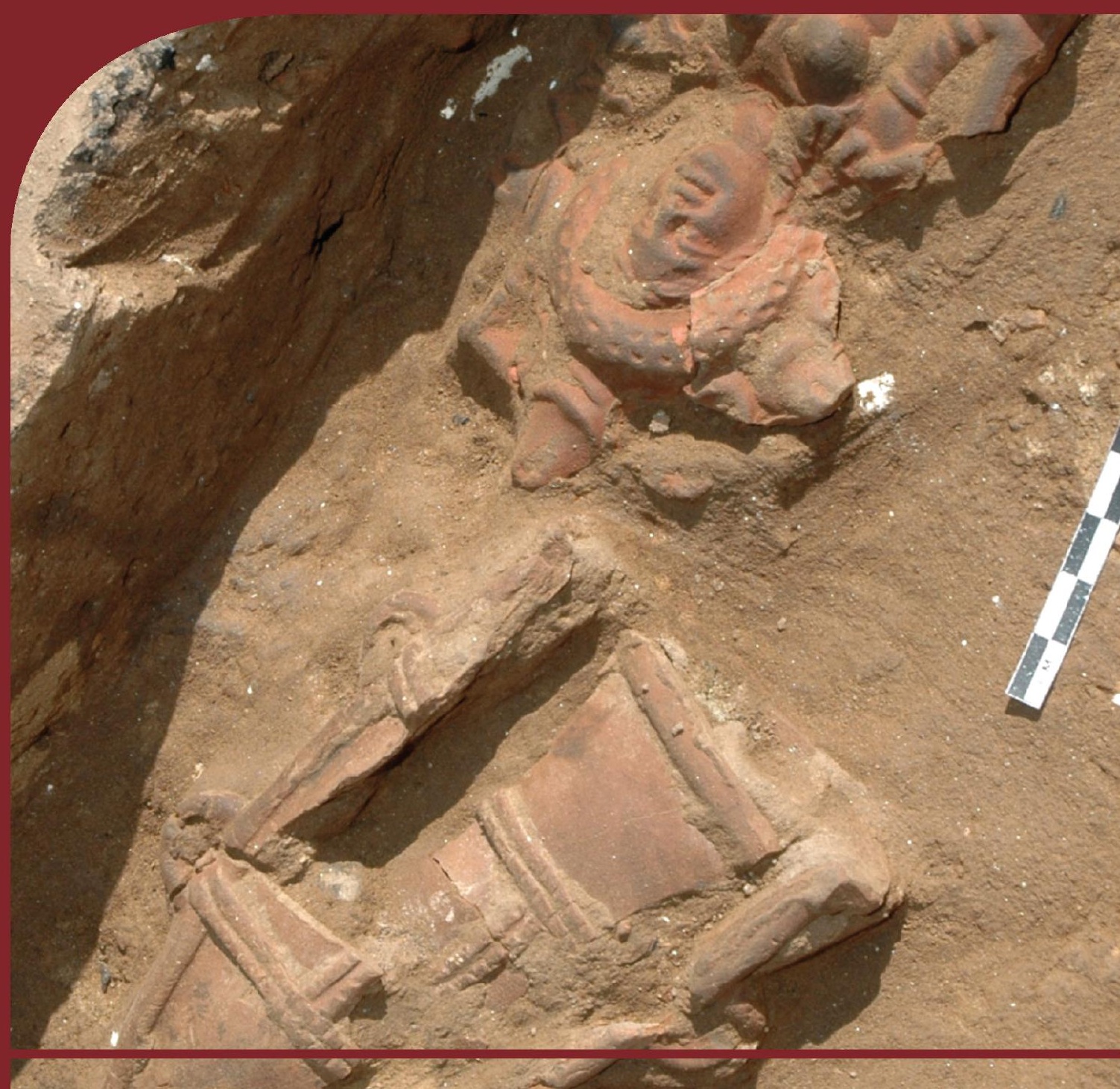

Institut des Cultures iyréditerranéennes et Oilentales FORIKSiO - de PAcadémie Polonaise des Sciences DS PA 


\section{COMITÉ DE RÉDACTION SCIENTIFIQUE}

Maciej Makowski - rédacteur en chef

Jadwiga Iwaszczuk - rédacteur

Mariusz Drzewiecki - sécretaire de la rédaction

Karol Myśliwiec - rédacteur thématique du volume

CONSEIL SCIENTIFIQUE DU JOURNAL

M. Kobusiewicz (IAE PAS, Warszawa), E. Laskowska-Kusztal (IMOC PAS, Warszawa)

D. Michaelides (University of Cyprus, Nicosia)

J.Ch. Moretti (IRAA-MOM, Université de Lyon 2/CNRS)

D. Raue (Ägyptisches Museum der Universität Leipzig), P. Reynolds (ICREA, España)

D. Welsby (British Museum, London)

\section{COMITÉ SCIENTIFIQUE DE LECTURE}

H.D. Baker (University of Toronto), P. Ballet (ArScAn-ESPRI, Université Paris Nanterre),

N. Beaux Grimal (IFAO, Cair/Collège de France, Paris), A. Dodson (University of Bristol),

L. Gabolde (CNRS), C. Gobeil (Egypt Exploration Society, London),

J. Holaubek (Institut für Ägyptologie, Wien), S. Ikram (American University in Cairo),

K. Innemée (Universiteit Leiden), Ch. Leitz (Universität Tübingen),

A. Loprieno-Gnirs (Universität Basel), Ch.E. Loeben (Museen für Kulturgeschichte, Hannover),

S. Ortisi (Universität München), A. Peignard-Giros (HiSoMA-MOM, Université de Lyon 2/CNRS),

E. Rova (Università Ca' Foscari Venezia), A. Sasson (San Diego Natural History Museum),

G. Schreiber (Eötvös Loránd University, Budapest), E. Teeter (University of Chicago),

Y. Tristant (Macquarie University, Sydney), V. Vaelske (independent researcher),

V.W.J. van Gerven Oei (independent researcher), H. Vymazalová (Charles University, Prague),

K. Winther-Jacobsen (Danish Institute at Athens),

J.A. Ostrowski, E. Papuci-Władyka, J. Śliwa (IA JU, Kraków),

R. Czerner (WUST, Wrocław), A. Ćwiek (IA AMU, Poznań),

K. Domżalski (IAE PAS, Warszawa), M. Pinker (FOS UW, Warszawa),

Ł. Niesiołowski-Spanò (IH UW, Warszawa), M. Gawlikowski (PCMA UW, Warszawa), K.O. Kuraszkiewicz (DE FOS UW, Warszawa), M. Barwik, P. Dyczek, W. Godlewski,

S. Rzepka, J. Żelazowski, A. Niwiński (IA UW, Warszawa)

\section{RÉDACTION TECHNIQUE}

Maciej Makowski, Jadwiga Iwaszczuk

CORRECTION LINGUISTIQUE

Jo Harper 
ÉTUDES et TRAVAUX

XXXI 
INSTYTUT KULTUR ŚRÓDZIEMNOMORSKICH I ORIENTALNYCH POLSKIEJ AKADEMII NAUK

\title{
STUDIA i PRACE
}

XXXI

\author{
gO IKŚiO \\ ESA PAN \\ WARSZAWA \\ 2018
}


INSTITUT DES CULTURES MÉDITERRANÉENNES ET ORIENTALES DE L'ACADÉMIE POLONAISE DES SCIENCES

\section{ÉTUDES et TRAVAUX}

XXXI

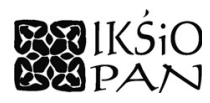

VARSOVIE

2018 
Publication scientifique financée dans le cadre du programme du Ministre de la Science et de l'Éducation Supérieure « Programme National de Développement de l'Humanistique » pour les années 2016-2021 (projet $n^{\circ} 3 \mathrm{bH} 15009983$ )

\title{
Harodowy PROGRAM ROZWOJU HUMANISTYKI
}

\author{
Copyright $($ ) \\ Instytut Kultur Śródziemnomorskich i Orientalnych PAN \\ et les Auteurs \\ Warszawa 2018
}

ISSN 2084-6762

(avant $2011: 0079-3566$ )

e-ISSN 2449-9579

Version première en papier, imprimée en Pologne - 150 copies

Version électronique accessible sur http://www.etudesettravaux.iksiopan.pl

Édition: Polskie Towarzystwo Historyczne et Wydawnictwo Neriton, Warszawa

Conception générale de couverture : J. Iwaszczuk Photo de couverture : P. Moser (C) Schweizerisches Institut für Ägyptische Bauforschung und Altertumskunde in Kairo

(terre cuites d'Aswan/Syene) 


\section{Table des matières}

KAROL MYŚLIWIEC

$(E T=E t u d T r a v / 50) \times 30$

HASSAN Aglan

Hatshepsut and the Apis Race: New Quartzite Relief Fragments

from Dra' Abu el-Naga

Amgad Joseph

Divine Wrath in Ancient Egypt

Amgad Joseph

Pain Infliction, Inflictors and Healers in Egyptian Religious, Magical

and Literary Perceptions

MirosŁaW BarwiK

New Dipinti in the Birth Portico of the Hatshepsut Temple at Deir el-Bahari

KrzyszTOF BorysŁaWsKi, ANNA NiwiŃSKA, ANDRZEJ NiwiŃSKI,

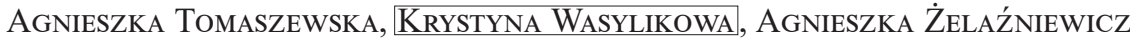

A Bulb of Narcissus on the Egyptian Mummy from University

of Wrocław Collection

LINDA CHAPON

Some Reliefs Representing the King in the Heb Sed Robe Discovered in the Henket-Ankh

Philippe Guillaume

Debunking the Latest Scenario on the Rise of the Pork Taboo

Mariola Hepa

A Clay Gladius Scabbard from Area 13c in the Ancient Roman Town of Syene

Emanuele E. Intagliata

Pinpointing Unrest at Palmyra in Early Islamic Period. The Evidence from Coin Hoards and Written Sources 
KATARZYNA KAPIEC

The Sacred Scents: Examining the Connection Between the ' $n t j w$ and $s f \underline{t}$ in the Context of the Early Eighteenth Dynasty Temples

DOMINIKA MAJCHRZAK

Remarks on the Iconographic Motif of the Birdman in Mesopotamian Glyptic Art of the Third Millennium BC

KAROLINA PAWLIK

Stone Artefacts from Late Roman Occupation Phases in Nea Paphos

ABRÉVIATIONS 
THE VOLUME IS PUBLISHED TO CELEBRATE

THE $50^{\text {TH }}$ ANNIVERSARY

OF THE

ÉTUDES ET TRAVAUX

ESTABLISHED IN 1966 